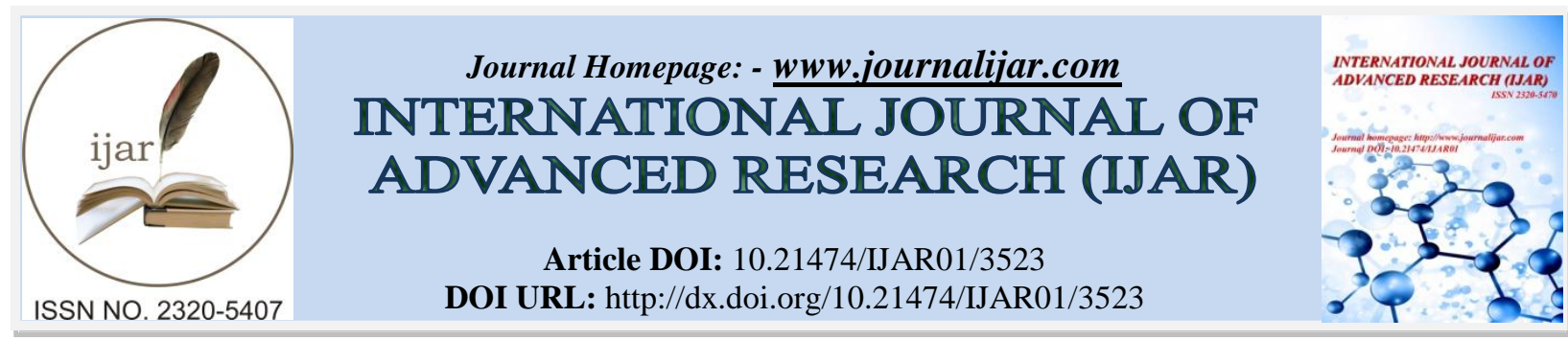

RESEARCH ARTICLE

\title{
COMPARISON OF MITOTIC EFFECT OF AQUEOUS, AICOHOL AND PETROLEUM ETHER EXTRACT OF THE LEAVES OF BOERHAAVIA DIFFUSA L.ON ROOT MERISTEM OF ALLIUM CEPA \\ L.
}

Rijuraj M.P. and C. T. Chandralekha.

Post Graduate Department Botany, Deva Matha College, Kuravilangad, Kottayam, Kerala, India

\section{Manuscript Info}

Manuscript History

Received: 13 January 2017

Final Accepted: 16 February 2017

Published: March 2017

Key words:-

Boerhaavia diffusa $\mathrm{L}$, Abnormal cells, Mitosis

\begin{abstract}
In the present study the effects of various extracts of Boerhaavia diffusa L. on mitotic cells of Allium cepa $\mathrm{L}$. is investigated. The concentrations are set as $0.05,0.1,0.15$ and 0.2 using water, petroleum ether and ethyl alcohol extract of stem and leaves. The duration of the treatment is 30 minutes prior to mitotic peak. The mitotic index and index of various stages of mitosis are scored along with the number of abnormal cells. The mitotic index is found to be reduced after higher concentration of treatments while at lower concentrations there is an increase in the number of dividing cells. The percentage of abnormal cells is found to be increased with increase in the concentration of the treatment. The abnormalities showed a predominance of stickiness than fragments, bridges, unoriented and tropokinesis. The results indicated that the active toxic element is an ethyl alcohol soluble fraction as evidenced by higher frequency of abnormal cells. Thus it is recommended that excessive use of ayurvedic preparations like purnavasasa, a preparation made entirely from Boerhaavia diffusa L. may harm the epithelial lining of stomach and intestine.
\end{abstract}

Copy Right, IJAR, 2017,. All rights reserved.

\section{Introduction:-}

Boerhaavia diffusa $\mathrm{L}$ is a perennial creeping weed, prostrate or ascending herb, up to $1 \mathrm{~m}$ long or more, having spreading branches. The roots are stout and fusiform with a woody root stock. The stem is prostrate, woody or succulent, cylindrical, often purplish, hairy, arranged in unequal pairs, green and glabrous above and usually white underneath. The shape of the leaves varies considerably-ovate-oblong, round, or sub cordate at the base and smooth above. Margins of the leaves are smooth, wavy or undulate. The upper surface of the leaves is green, smooth, and glabrous, where as it is pinkish white and hairy beneath. Leaves are up to $5.5 \times 3.5 \mathrm{~cm}^{2}$ in area.

Flowers are minute, sub capitates, present 4-10 together in small bacteriolate umbels, forming axillary and terminal panicles. These are hermaphrodite, and white, pink, or pinkish red in color. Bracts are deciduous and involucrate. A perianth is present in the place of a calyx and corolla, which is tubular in shape, the tube being short and narrow at the base and funnel. Shaped at the top and constricted above the ovary. There are five lobes, which are small and acute. Two or three stamens are present and are slightly exerted. The stigma is peltate. The achene fruit is detachable, ovate oblong, pubescent, five ribbed and glandular, anthocarpous, and viscid on the ribs (Thakur et al., 1989). The seed germinate before the onset of the monsoon.

Corresponding Author:- Rijuraj M P.

Address:- Post Graduate Department Botany, Deva Matha College, Kuravilangad, Kottayam, Kerala, India.email: rijurajmp@gmail.com 
The plants grow profusely in the rainy season, and mature seeds are formed in October- November. Due to its sticky nature, the plant gets stuck on clothes of human beings and on the legs of animals, which helps in it dispersal from one plane to another. It has a large root system bearing rootlets. The tap root is tuberous, cylindrical to narrowly fusiform to conical or tapering, light yellow, brown or brownish gray. Some workers have studied the regeneration of this plant through tissue culture. Bhansali et al., (1978) reported induct on of adventitious shoots using stem explants of Boerhaavia diffusa L. Roots were also regenerated from and leaf segments of Boerhaavia diffusa $\mathrm{L}$ when cultured in vitro. These roots contained $0.15 \%$ alkaloid punarnavine. Increase in leaves of iodoleacetic acid (IAA) in MS medium reduced the number of roots regenerate from the leaf segment, their length and alkaloid content (Shrivastava and Padhya, 1995).

In purulia (West Bengal), tribal eat this plant as vegetable. Boerhaavia diffusa L leaves are cooked and eaten in Assam, where it is commonly found in the markets. Its roots are used in the treatment of piles by the inhabitants of the Garhwal Himalaya (Uttaranchal). The root paste is used to cure bloody dysentery by the Bhils of the Jhabua district in Madhya Pradesh. The decoction of plant is given in the treatment of nodules in the body. The root juice is treating asthma, scanty urine, and internal inflammation disorders. Boerhaavia diffusa $\mathrm{L}$ is used for curing ailments such as leucorrhea, rheumatism, and stomach ache by the sahariya tribe in the Lalitpur district of Uttar Pradesh. This plant is also used by the tribes of Ambikapur district (Madhya Pradesh) for the treatment of elephantiasis. In the Indo-Nepal Himalayan terrain region, the tribal harvest this plant for medicinal purposes, mainly for flushing out the renal system, and to treatment seminal weakness and blood pressure ( Mitra and Gupta,1997).

The Boerhaavia diffusa L plant contains a large number of compounds as flavonoids, alkaloids, steroids, triterpenoids, lipids, lignins, carbohydrates, proteins and glycoproteins . Punarnavine $\mathrm{C}_{17} \mathrm{H}_{22} \mathrm{~N}_{2} \mathrm{O}$, (Surange and Pendse,1972), boeravinone A.F(Kadota etal.,1989; Lami et al.,1992), hypoxanthine 9-L-arabinofuranoside (Ahmad and Hossain,1968), ursolic acid (Mishra andTiwar;1971), punarnavoside (Jain and Khanna,1989), liitodendrin (Aftab et al,1996) and agiycoprotein having a molecular weight of 16-20 KDa have been isolated and studied in detail for their biological activity Chopra et al., (1923) reported that the plant contained large quantities of potassium nitrate,besides punarnavine. The herb and roots are rich in proteins and fats .The herb contains 15 aminoacids, including 6 essential aminoacids, while the root contains 14 aminoacids . Seth et al., (1986) isolated a new antifibrinolytic compound 'punarnavoside' from the roots of Boerhaavia diffusa L. Phytochemical screening of the roots from garden - grown in vivo plants of Boerhaavia diffusa $\mathrm{L}$ of different ages revealed that the maximum alkaloid content $(2 \%)$ accumulated in the roots of 3 year old mature plants.

\section{Biological Activity:-}

As medicine in the traditional system:Different parts of the Boerhaavia diffusa L plants have been widely used by indigenous tribes in the traditional system of medicine. The roots have been widely used for treatment of dyspepsia, jaundice, and enlargement of spleen, abdominal tumors and cancers (Kirtikar and Basu, 1956). The root powder, when mixed with mamira (Thalictrum foliolosm DC), is used to eye diseases. It cures corneal ulcers and night blindness (Gupta et al., 1962), and helps restore virility in men. People in tribal areas use it to hasten childbirth (Shah et al., 1983). The juice of Boerhaavia diffusa $\mathrm{L}$ leaves serves as a lotion in ophthalmia. It is also administered orally as a blood purifier and to relieve muscular pain.

As medicine in the ayurvedic system: In old Indian books of medicine such as the Charaka Samhitha and Sushrita Samhita, it mentioned that the Ayurvedic preparations made from punarnava-namly, punarnanavastaka kvath, punarnava kshar, and punarnava taila-were used for the treatment of various ailments. The whole plant of Boerhaavia diffusa $\mathrm{L}$ is very useful source of the drug punarnava, which is documented in Indian pharmacopoeia as a diuretic (Chopra, 1969). The active principle contained in the herb is an aikaloid, known as punarnavane. The roots and leaves with flowers have been found to be highly potent (CSIR, 1988). In Ayurvedic medicine, different parts of this plant were reported to have various medicinal properties. It was used in renal ailments as diuretic (Anand, 1995); and to treat seminal weakness and blood pressure (Gaitonde et al., 1974). It is also used in the treatment of stomach ache, anemia, cough, and cold, and as a diaphoretic, laxative, expectorant, and a potent antidote for snake and rat bites(Chopra et al.,1956), in the treatment of nephritic syndrome(Singh and Udupa, 1972 ), hepatitis, gall bladder abnormalities , and urinary disorders (Cruz,1995). The flowers and seeds are used as contraceptive (Chopra et al., 1956). 
Pharmacological and clinical properties:Pharmacological studies have demonstrated that punarnava possesses punarnavoside, which exhibits awide range of properties- diuretic (Gaitonde et al.,1974); anti-inflammatory (Bhalla et al., 1968); antifibrinolytic (Jain and Khanna,1989); anticonvulsant(Adesina,1979); antibacterial (Olukoya et al ,1993); antistress agent; antihepatotoxic , anthelmintic, febrifuge , antiscabies, and anti-asthmatic,antileprosy, and anti-urethritis and anti-nematodal activity. An aqueus extract of thinner roots of (Boerhaavia diffusa L) at a dose of $2 \mathrm{ml} \mathrm{kg}^{-1}$ exhibited marked protection of various enzymes such as serum glutanic oxaloacetin trasaminase, serum glutanic- pyruvic trasaminase, and bilirubin in serum against hepatic injury in rats. Punarnava possesses diuretic and ant-inflammatory activities and the maximum activity was observed in samples collected in the rainy season. Due to the combination of these two activities, punarnava is regarded therapeutically as highly efficacious for the treatment of inflammatory renal diseases and common clinical problems such, as nephritic syndrome, oedema, and ascites resulting from early cirrhosis of the liver and chronic peritonitis.

The plant is reported to be efficacious in abdominal tumors and cancers. The drug proved useful as a hematinic and as a growth in children fed with milk fortified with the drug. In the form of a power or an aqueous decoction, the drug was found to be useful in the treatment of nephritic syndrome and compared well with corticosteroids. The drug decreased to albumin urea, the serum protein was increased and serum cholesterol level was lowered.

Singh and Udupa (1972) reported that dried root powder showed curative efficiency when administered orally for one month to children or adults suffering from helminths infection. The subjects become warm- free within five days of treatment. The drug singly or in combination with other drugs, was found to be effective in liver disorders, heart diseases (hypertension, angina, cardiac failure, etc), respiratory tract infections, leucorrhea, spermatorrhea, etc. The purified glycoprotein from Boerhaavia diffusa L exhibited strong antimicrobial activity against RNA (ribonucleic acid) bacteriophages with much of clinical research validating its long history of different uses in natural medicine; the commercial bulk of punarnava in India represents heterogenous medicinal uses.

As food: The entire plant including the roots is eaten as vegetable, in curries and soups. The roots and seeds are added to cereals, pancakes, and other food stuffs. They are also served as bird feed or poultry feed. The plants are grazed by sheep, goats, and cows, and in West Bengal, it is believed that the plant enhances lactation period and also the amount of milk in cattle.

Significance of the Study:-

Boerhaavia diffusa $\mathrm{L}$ have been used in ayurvedic preparation for millennia. The scientific studies as well as the exploration of active principles are developed in recent years. In resent year of research have to reveal that many of such potent and effective during sources contain mutagenic or cytotoxic principles. This raises concern about the genotoxic hazards resulting from long term use of such plants. This is because of the fact that plant extract contains mainly alkaloids, glycoside, flavonoides, tannins etc . Because of the low cost of the ayurvedic preparations as well as its local availability, people can afford the long term use of such preparations. In view of these, the cytotoxic effect of the various fraction of Boerhaavia diffusa $\mathrm{L}$ is essential, and is attempted in this study.

\section{Objectives of the Study:-}

The present study is focused on to find out the effect of various fractions of extract of Boerhaavia diffusa $\mathrm{L}$ on mitotic index and variations in different phases of cell division in root meristem cells of Allium cepa $\mathrm{L}$. This study also find out the nature and intensity of aberrations of dividing cells caused by various fractions of the extract of Boerhaavia diffusa $\mathrm{L}$ and the LC50 of the extract of Boerhaavia diffusa $\mathrm{L}$ with respect to the cell damage in Allium cepa $\mathrm{L}$ meristem.

\section{Materials and Methods:-}

\section{The material:-}

Boerhaavia diffusa $\mathrm{L}$ grown in wild condition were collected for the study. The plants were identified up rooted and bring to the laboratory.

Preparation of the plant material:-

The leaves of mature flowered twigs are separated and shade dried and oven dried at $60^{\circ} \mathrm{C}$ up to attaining a constant weight. The dried material was powdered and sieved. 


\section{Soxhlet extraction:-}

The powdered material was extracted using petroleum ether, ethyl alcohol and water in a Soxhlet for 8 hours. The fractions were collected and dried.

\section{The onion culture:-}

Commercially available bulbs of Allium cepa $\mathrm{L}$ were used for the study well cleaned bulbs were sown in well ministered sterile sand, in a tray of size $30 \times 26 \mathrm{~cm}$. The germinated bulbs with $0.5-1 \mathrm{~cm}$ roots were selected and treated with different concentrations of extracts $(0.05 \%, 0.1 \%, 0.15 \%, 0.2 \%)$ of Boerhaavia diffusa $\mathrm{L} 5$ bulbs were treated for each concentration.

\section{Collection of root tip and storage:-}

The root tip after treatment are cut out from the bulbs and washed well in distilled water. Transfer the root tip in to Carnoy's fixative ( 3 alcohol: 1 acetic acid) for 24 hours; and then stored at $4^{0} \mathrm{C}$.

\section{Squashing and staining:-}

Stored root tips are hydrolyzed in $1 \mathrm{~N} \mathrm{HCl}$ for 3 minutes and washed well in water. Squash preparation of these root tips were made with $2 \%$ acetocarmine stain, and observed under microscope. Five slides are scored for evaluation. Three randomly selected fields are scored from each slide. Control is maintained for each treatment in distilled water.

\section{Observations taken:-}

The total number in cell in each field along with the number of dividing cells was scored. The total number cells pertaining to each phases of division was also noted.

The mitotic index were calculated rising the formula,

$$
\text { Mitotic index }=\frac{\text { Number of dividing cells }}{\text { Total number of cells }} \times 100
$$

Percentage distribution of normal and abnormal cells, percentage of various abnormalities met with are presented in Tables and compared with control.

\section{Results and Discussion:-}

A careful analysis of the data revealed that the treatment with aqueous extracts of leaves of Boerhaavia diffusa $\mathrm{L}$ on mitotic cells of the Allium cepa L showed an increase in mitotic index when compared to control. The increase was not depended on the concentration of the extract treated. The control posses of an index of $15.70 \%$ while in treated cells possess $24.51,30,33.3$ and 21.67 percent of dividing cells after treatments with $0.05,0.1,0.15$ and 0.2 percent of extract respectively. Similar concentrations of alcoholic extracts yielded 22.05, 20.56, 16.14 and 13.47percent of mitotic cells. The petroleum ether extracts of leaves of Boerhaavia diffusa L mitotic cells of the Allium cepa $\mathrm{L}$ yielded 11.13, 13.37, 13.12 and 14.09 percent mitotic index after treatment with $0.05,0.1,0.15$ and 0.2 percent of extract respectively.

Table 1:- Mitotic index of root meristem of Allium cepa $\mathrm{L}$ after treatment with extract of leaves of Boerhaavia diffusa L.

\begin{tabular}{|c|c|c|c|}
\hline $\begin{array}{c}\text { Concentration of } \\
\text { Treatment in percentage }\end{array}$ & \multicolumn{3}{|c|}{ Mitotic Index } \\
\cline { 2 - 4 } & $\begin{array}{c}\text { Alcoholic Leaf } \\
\text { extraction }\end{array}$ & $\begin{array}{c}\text { Petroleum ether Leaf } \\
\text { extraction }\end{array}$ & Water Leaf extraction \\
\hline Control & 15.70 & 15.70 & 15.70 \\
\hline 0.05 & 22.05 & 11.13 & 24.51 \\
\hline 0.1 & 20.56 & 13.37 & 30.00 \\
\hline 0.15 & 16.14 & 13.12 & 33.30 \\
\hline 0.2 & 13.47 & 14.09 & 21.67 \\
\hline
\end{tabular}




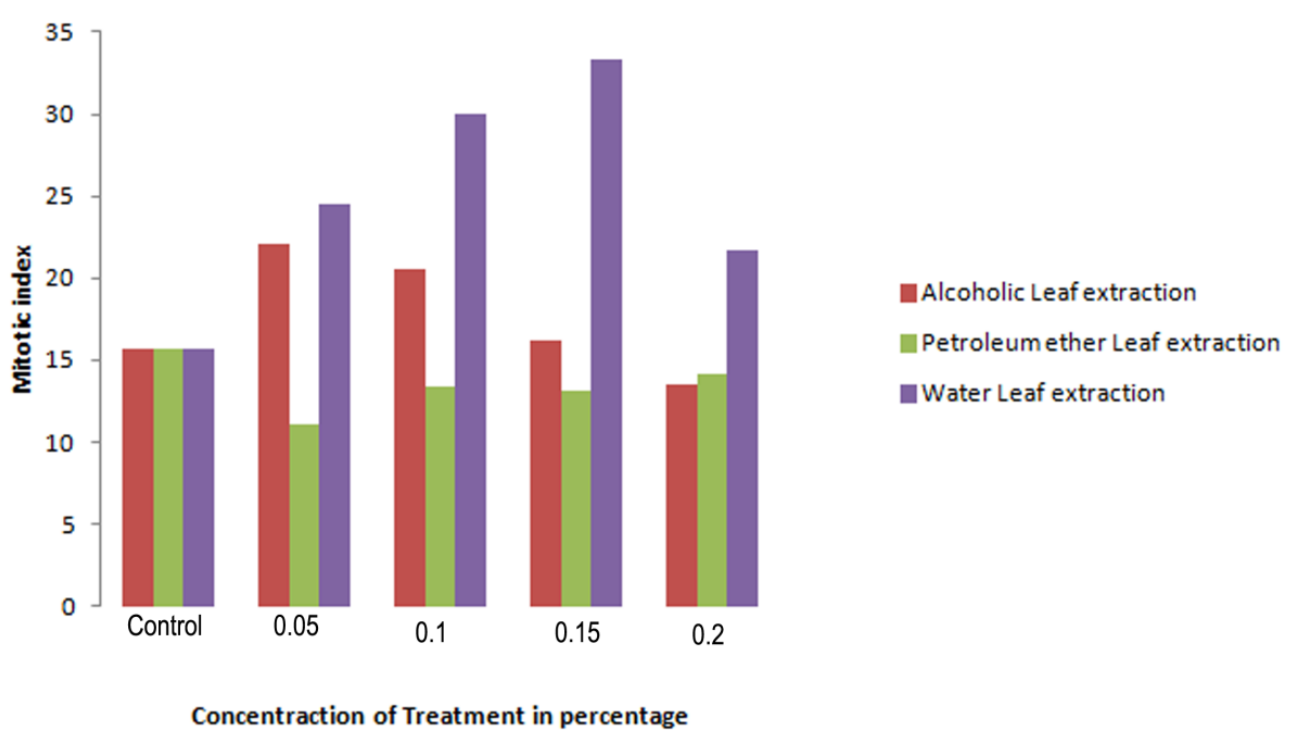

Graph 1:- Mitotic index of root meristem of Allium cepa L after treatment with extract of leaves of Boerhaavia diffusa $\mathrm{L}$.

The distribution of various stages of mitosis is also considered after treatment with various concentration of extract from leaves of Boerhaavia diffusa L. The distribution of dividing cells in control population is 80percent prophase, 4.87 percent metaphase, 7.80 percent anaphase and 7.30 percent of cells at telophase. After treatment with various concentration of ethyl alcohol extracts of leaves of Boerhaavia diffusa $\mathrm{L}$ this distribution is disturbed and resulting in 26.3 prophase, 47.36 metaphase, 10.52 anaphase and 15.79 telophase percentages treated with 0.2 percent extract. After treatment with 0.15 percent extract the distribution is found to be 54.83 prophase, 22.58 metaphase, 10.90 anaphase, and 9.60 telophase percents. After treatment with 0.1 percent extract the distribution is found to be 51.72 prophase, 31.03 metaphase, 17.26 anaphase and no percenages telophase at all. However treatment with 0.05 percent of extract of leaves of Boerhaavia diffusa L showed 82.22 percent prophase, 8.80 percent metaphase, 6.66 percent anaphase and 2.20 percent telophase.

With respect to the presence of abnormal cells the treatment with alcohol extracts of leaves of Boerhaavia diffusa $\mathrm{L}$ on Allium cepa $\mathrm{L}$ induces $63.15 \%$ after treatment with 0.15 extract, which forms the highest percentage of abnormal cells observed in the present study. The increase in the number of abnormal cells was not depended on the concentration of the extract treated. The percentage of abnormal cells observed after various concentrations of treatment is presented in Table. 3.

The percentages of various abnormalities produced by extract in different solvents as well as from leaves of Boerhaavia diffusa $\mathrm{L}$ are given Table.4. The most observed abnormalities observed were stickiness, fragment, unoriented, bridge and tropokiness. Metaphase stickiness was found to be the most common anomaly (42.10 in alcoholic extract of leaves) this was followed by unoriented chromosomes in metaphase $(22.58 \%$ in alcoholic extract of leaves), prophase stickiness (3.70 percent in petroleum ether extract of leaves), anaphase tropokinensis (10.34 percent in petroleum ether extract of leaves), anaphase bridge (9.67 percent in alcoholic extract of leaves), telophase stickiness (6.896 percent in petroleum ether extract of leaves). Apart from these metaphase fragments (2.86 percent) due to treatment with alcoholic extract of stem, telophase bridge ( 1.31 percent due to treatment with water extract of leaves) and telophase tropokinesis (1.18 percent) due to treatment with alcoholic extract of stems are also observed (Table 4).Other extract treatments results are also seen in Table 4. 
In general, the mitotic index decreases with increasing distance from the root cap junction. Cells of the root cap protect the root and must be constantly replaced as they are damaged or scraped away. The apical meristem, just beneath the root cap, contains most of the root's dividing cells. Therefore, cells in this area must complete the cell cycle often. Some daughter cells become part of the root cap, others differentiate and elongate into primary tissues of the root. If we allow growing roots to take up a radioactive precursor of DNA, almost all of the labeled cells lie in the meristem.

The mitotic index can also be used to quantify differences in cell division when an environmental parameter is changed. Plants grown in space in microgravity had a greater mitotic index than control plants grown on the ground. In zero-gravity, the gravity sensing cells in the root cap are unable to send the proper orientation signals. These signals normally inhibit growth in cells that are more distant from the root cap junction, and direct elongation of the primary root. In the absence of these signals, cells begin dividing to produce secondary roots, leading to a greater number of cells in mitosis.

Table 2:- Distribution of percentage dividing cells at various stages of mitosis of Allium cepa L. after treatment with aqueous, alcoholic, petroleum ether extracts of leaves of Boerhaavia diffusa $\mathrm{L}$.

\begin{tabular}{|c|c|c|c|c|c|c|c|c|c|c|c|c|}
\hline $\begin{array}{c}\text { Concentration } \\
\text { of treatment } \\
\text { in percentage }\end{array}$ & \multicolumn{9}{|c|}{$\begin{array}{c}\text { Percentages of dividing cells at } \\
\text { extraction }\end{array}$} & \multicolumn{4}{|c|}{$\begin{array}{c}\text { Metaphase in leaves } \\
\text { extraction }\end{array}$} & \multicolumn{3}{c|}{$\begin{array}{c}\text { Anaphase in leaves } \\
\text { extraction }\end{array}$} & \multicolumn{3}{|c|}{$\begin{array}{c}\text { Telophase in leaves } \\
\text { extraction }\end{array}$} \\
\cline { 2 - 14 } & $\mathbf{A}$ & $\mathbf{P E}$ & $\mathbf{W}$ & $\mathbf{A}$ & $\mathbf{P E}$ & $\mathbf{W}$ & $\mathbf{A}$ & $\mathbf{P E}$ & $\mathbf{W}$ & $\mathbf{A}$ & $\mathbf{P E}$ & $\mathbf{W}$ \\
\hline Control & 80.00 & 80.00 & 80.00 & 4.87 & 4.87 & 4.87 & 7.80 & 7.80 & 7.80 & 7.30 & 7.30 & 7.30 \\
\hline 0.05 & 82.22 & 41.94 & 57.89 & 8.80 & 17.74 & 11.84 & 6.66 & 29.03 & 9.21 & 2.20 & 11.29 & 9.21 \\
\hline 0.1 & 51.72 & 46.29 & 70.67 & 31.03 & 18.52 & 10.67 & 17.26 & 25.92 & 8.00 & 0 & 9.26 & 8.00 \\
\hline 0.15 & 54.83 & 36.21 & 66.67 & 22.58 & 10.34 & 15.48 & 12.90 & 41.38 & 8.93 & 9.60 & 12.07 & $8 . .93$ \\
\hline 0.2 & 26.31 & 29.63 & 63.07 & 47.36 & 24.07 & 13.85 & 10.52 & 33.33 & 10.77 & 15.79 & 12.96 & 10.77 \\
\hline
\end{tabular}

A- Alcoholic extraction of Boerhaavia diffusa L. leaves, PE- Petroleum ether extraction of Boerhaavia diffusa L. leaves, W- Water extraction of Boerhaavia diffusa L. leaves.

According to Badr and Ibrahim (1987) decrease of mitotic index level shows that experimental material had mitodepressive effect resulting in the inhibition of cells access to mitosis. It means that the treatment disturbs the normal cell cycle process by preventing biosynthesis of DNA and/or microtubule formation. Hence, this effect could be formed by decreased ATP level or suppression of the engine of energy production. Reduction in the mitotic activity could be due to inhibition of DNA synthesis or a blocking in the G2-phase of the cell cycle, preventing the cell from entering mitosis.

The common abnormalities are stickiness, fragment, unoriented chromosomes and bridges. Stickiness was seen in prophase, metaphase, anaphase and telophase. Fragment was seen in metaphase. Unoriented chromosomes were observed in metaphase and anaphase. Bridges was seen in anaphase and telophase. The types of abnormalities scored in this investigation resemble those reported by Somashekhar and Goda (1984). It has been suggested by them that stickiness is a type of physical adhesion involving mainly the proteinacious matrix of chromatin material.

Table 3:- Percentage of abnormal dividing cells at mitosis of Allium cepa $\mathrm{L}$ after treatment with various concentrations of aqueous, alcoholic, petroleum ether extract of leaves of Boerhaavia diffusa $\mathrm{L}$

\begin{tabular}{|c|c|c|c|}
\hline \multirow{2}{*}{$\begin{array}{c}\text { Concentration of } \\
\text { Treatment in percentage }\end{array}$} & \multicolumn{3}{|c|}{ \% of abnormal cells } \\
\cline { 2 - 4 } & Alcoholic Leaf extraction & $\begin{array}{c}\text { Petroleum ether Leaf } \\
\text { extraction }\end{array}$ & Water Leaf extraction \\
\hline Control & 0 & 0 & 0 \\
\hline 0.05 & 15.78 & 33.87 & 15.78 \\
\hline 0.1 & 52.63 & 25.92 & 13.33 \\
\hline 0.15 & 63.15 & 50.00 & 18.45 \\
\hline 0.2 & 57.89 & 40.74 & 18.46 \\
\hline
\end{tabular}


The fragments may be a result of breaks since many reports point out that elevated frequency of aberrations is in the form of chromosomal breaks. The sticky bridges resulted from difficulty in anaphase separation due to adhesion or clumping of chromosomes or to depolymerization and cross linking of the DNA of the chromosomes. El-Ghamery, (2000) report that chromosome bridges may be due to the chromosomal stickiness and subsequent failure of free anaphase separation or may be attributed to unequal translocation or inversion of chromosomal segments leading to mutations.

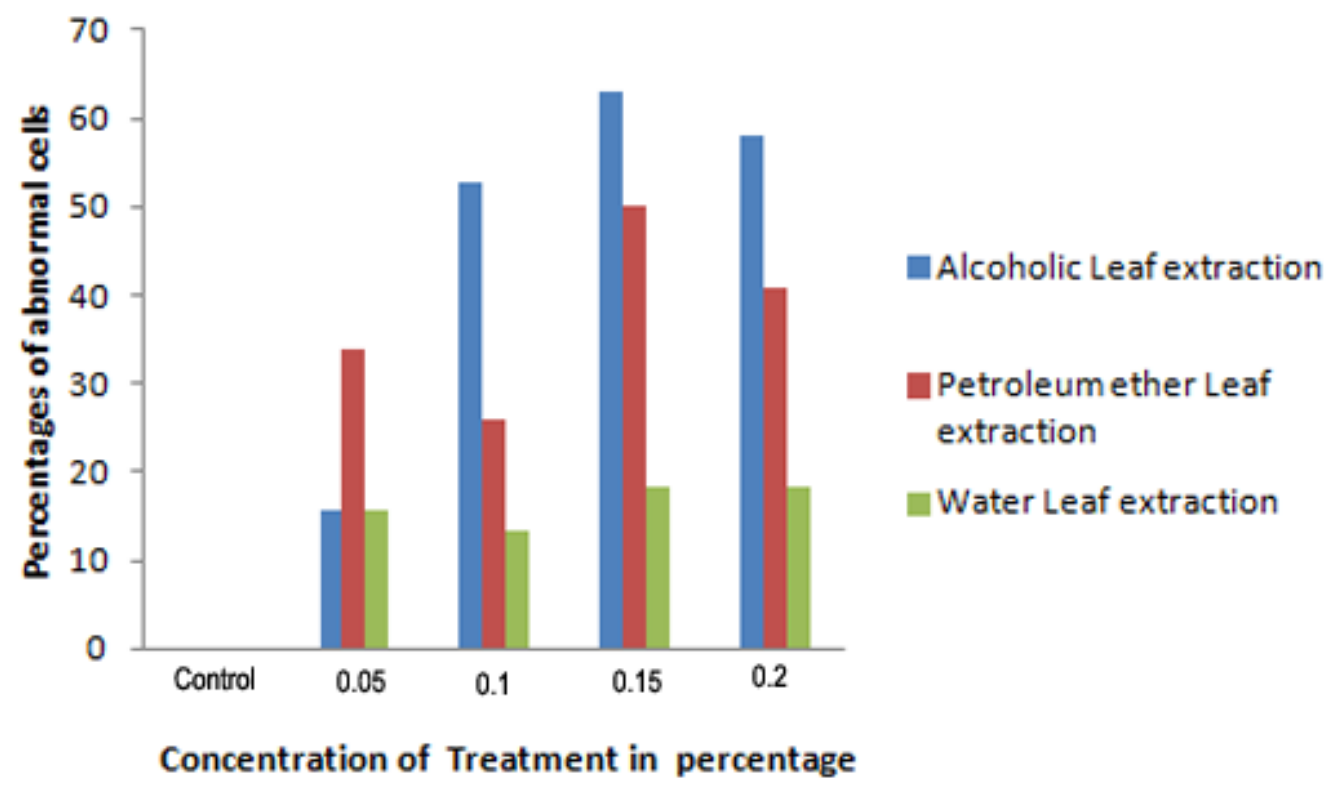

Graph 2:- Percentage of abnormal dividing cells at mitosis of Allium cepa L after treatment with various concentrations of aqueous, alcoholic, petroleum ether leaf extract of Boerhaavia diffusa $\mathrm{L}$

Table 4:- Percentage of abnormalities at various stages of mitotic division in Allium cepa $\mathrm{L}$ after treatment with alcoholic, petroleum ether and water extract of leaves of Boerhaavia diffusa L.

\begin{tabular}{|c|c|c|c|c|c|c|c|c|c|c|c|c|c|}
\hline \multicolumn{2}{|c|}{$\begin{array}{l}\text { Concentration of } \\
\text { treatment }(\%)\end{array}$} & \multicolumn{3}{|c|}{$0.05 \%$} & \multicolumn{3}{|c|}{$0.1 \%$} & \multicolumn{3}{|c|}{$0.15 \%$} & \multicolumn{3}{|c|}{$0.2 \%$} \\
\hline Stage & $\begin{array}{l}\text { Abnorma } \\
\text { lity }\end{array}$ & $\mathbf{A}$ & PE & $\mathbf{W}$ & $\mathbf{A}$ & PE & $\mathbf{W}$ & $\mathbf{A}$ & PE & $\mathbf{W}$ & $\mathbf{A}$ & $\mathbf{P E}$ & $\mathbf{W}$ \\
\hline Prophase & Stickiness & 2.22 & 3.22 & 6.58 & 6.89 & 3.70 & 6.67 & - & 3.45 & 5.95 & - & 1.85 & 7.69 \\
\hline \multirow[t]{3}{*}{$\begin{array}{l}\text { Metaphas } \\
\text { e }\end{array}$} & Stickiness & - & 3.22 & 1.31 & 6.89 & 1.85 & 0.67 & - & - & 1.19 & $\begin{array}{c}42.1 \\
0\end{array}$ & - & - \\
\hline & Fragment & - & - & - & - & - & - & - & - & - & - & 1.85 & - \\
\hline & $\begin{array}{l}\text { Unoriente } \\
\mathrm{d}\end{array}$ & 2.22 & 6.45 & 1.31 & $\begin{array}{c}17.2 \\
4 \\
\end{array}$ & 5.56 & 2.67 & 22.58 & 10.34 & 4.17 & - & 9.26 & 6.15 \\
\hline \multirow[t]{3}{*}{ Anaphase } & Stickiness & - & $\begin{array}{c}16.1 \\
3\end{array}$ & 1.31 & - & 5.56 & - & 3.22 & 15.52 & 5.36 & 5.26 & $\begin{array}{c}12.9 \\
6\end{array}$ & - \\
\hline & Bridge & 2.22 & 3.22 & 2.63 & 6.89 & 5.56 & 2.67 & 9.67 & 3.45 & 0.59 & 5.26 & 9.26 & - \\
\hline & $\begin{array}{l}\text { Tropokine } \\
\text { ss }\end{array}$ & - & - & - & - & 3.70 & $\begin{array}{c}0.06 \\
7\end{array}$ & 3.22 & 10.34 & - & - & 3.70 & 1.54 \\
\hline \multirow[t]{3}{*}{ Telophase } & Bridge & - & - & 1.31 & - & - & 0.67 & - & - & - & - & - & - \\
\hline & Stickiness & - & 1.61 & - & - & - & 1.33 & - & 6.896 & 1.19 & 5.26 & 1.85 & - \\
\hline & $\begin{array}{l}\text { Tropokine } \\
\text { ss }\end{array}$ & - & - & 1.31 & - & - & - & - & - & - & - & - & - \\
\hline
\end{tabular}

A- Alcoholic extraction of Boerhaavia diffusa L. leaves, PE- Petroleum ether extraction of Boerhaavia diffusa L. leaves , W- Water extraction of Boerhaavia diffusa L. leaves. 


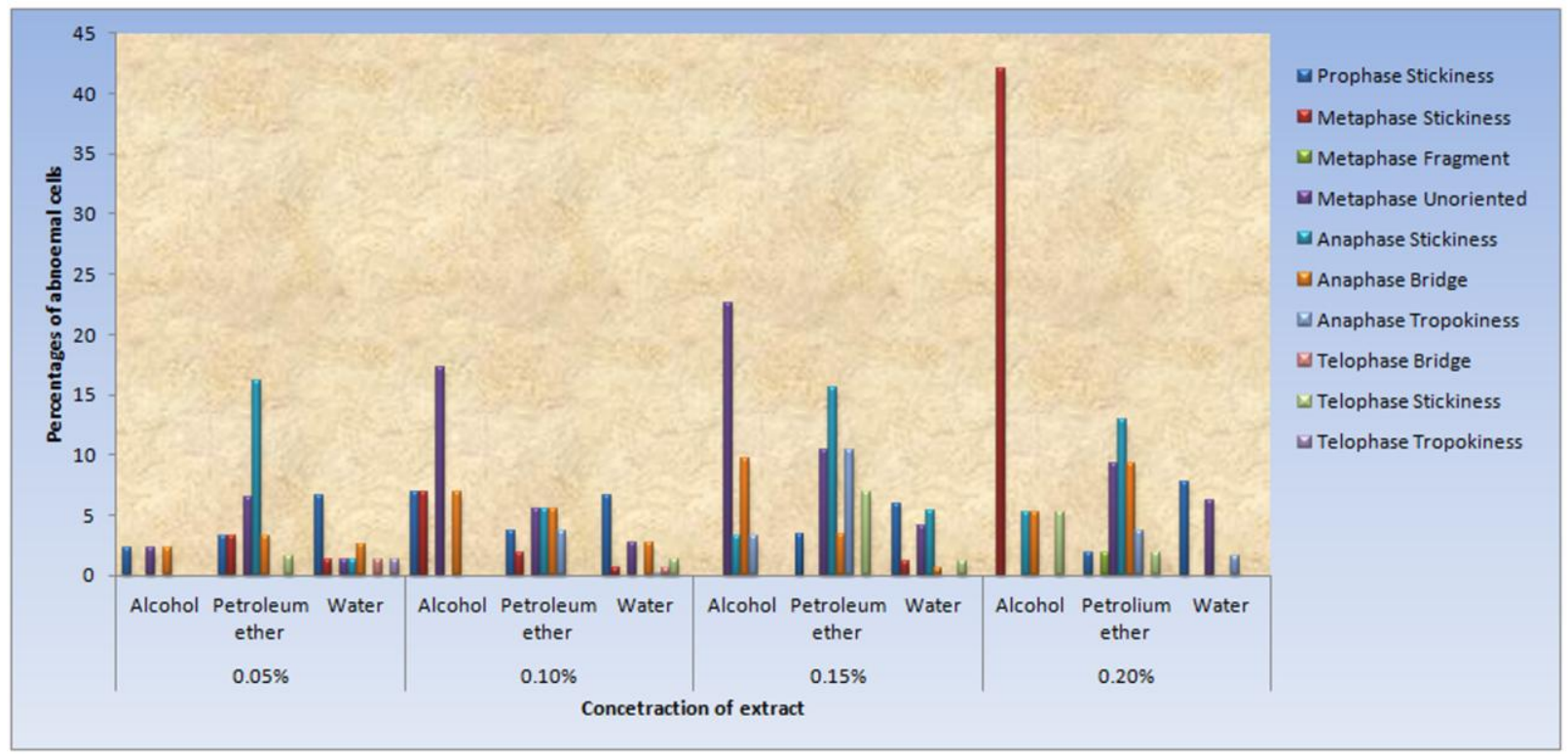

Graph 3:- Percentage of abnormalities at various stages of mitotic division in Allium cepa $\mathrm{L}$ after treatment with leaves extract of Boerhaavia diffusa $\mathrm{L}$

\section{Conclusion:-}

In the present study the effects of various extracts of Boerhaavia diffusa $\mathrm{L}$ on mitotic cells of Allium cepa $\mathrm{L}$. is investigated. The mitotic index is found to be reduced as the treatment concentration increases. But at low concentration there showed an enhancement in the number of dividing cells. The percentage of abnormal cells is found to be increased with increase in the concentration of the treatment. The common abnormalities observed are unoriented chromosomes at metaphase, fragments, tropokinesis, and bridges along with a predominance of stickiness. The results indicated that the there exists a toxic principle in Boerhaavia diffusa $\mathrm{L}$ and excessive use of its preparation may leads to anomalies in epithelial linings. Further studies are inevitable for understanding the component present in the extract which is responsible for cellular damage produced in root meristem of Allium cepa Land prolonged use of Boerhaavia diffusa L leaves as vegetable, good or badly affect epithelial linings of human.

\section{Acknowledgement}

The authors are grateful to the Principal, Dr Tharsis Joseph and Dr Varghese M C, Assistant Professor, Department Botany, Deva Matha College, Kuravilangad, Kottayam for various help in their research activities.

\section{References:-}

1. Adesina,S.K. 1979. "Anticonvulsant properties of the roots of Boerhaavia diffusa $(L)$. Quarterly Journal of Crude Drug Research .17:84-86.

2. Aftab.K.,Usmani,S.R.,Ahmad,S.I., and Usmanghani,K. 1996. "Naturally occurring calcium channel blockers-II'. Hamdard Medicus. 39:44-54.

3. Ahmad,K.and Hossain, A. 1968. "Isolation, synthesis and biological action of hypoxanthine-9-Larabinofuranoside". Journal of Agrecultural and biological sciences .11:41.

4. Anand, R.K. 1995. "Biodiversity and tribal association of Boerhaavia diffusa in IndiaNepal Himalayan Terai Region.Flora \& Fauna'. VI(2):167-170.

5. Aswathi, L.P, and Mukharjee, K. 1980. Protection of potato virus X infection by plant extracts. Biologia Plantarum 22: 205-209.

6. Aswathi, L.P., Pathak, S.P., and Gautham, N.C. 1985. Control of virus disease of vegetables crops by a glycoprotein isolated from Boerhaavia diffusa. Indian Journal of Plant Pathology 3:311-327. 
7. Aswathi, L.P. and Rizvi, S.M.A. 1998. Prevention of infection of a vector borne virus of tomato by Boerhaavia diffusa glycoprotein. In: Abstracts, XIII Annual Convention of the Indian Virological Society, and National Symposium on Characterization and Management of Viruses, 10-12 Oct 1998, NBRI and Lucknow University, Lucknow, Uttar Pradesh, India. Abstract no. 27.

8. Aswathi, L.P. and Rizvi, S.M.A. 1999. Effect of Boerhaavia diffusa glycoprotein on the transmission of tomato yellow leaf curl virus by Bemisia tabaci Gen. In: Abstarcts, National Symposium on Vectors of Plant Diseases, 11-13 Nov 1999, Nrendra Dev University of Agriculture and Technology, Kumarganj, Faizabad, UttarPradesh, India. P. 56.

9. Badr, A. and A.G. Ibrahim. 1987. Effect of herbicide Glean on mitosis, chromosomes and nucleic acids in Alium cepa and vicia faba root meristems. Cytologia, 52: 293-302.

10. Basu, N.K., Lal, S.B., and Sharma, S.N. 1947. Investigations on Indian medicinal plants. Quarterly Journal of Pharmacy and Pharmacology 20: 38-42.

11. Bhalla, T.N., Gupta, M.B., Sheth, P.K., and Bhargava, K.P. 1968. Antiinflammatory activity of Boerhaavia diffusa. Indian Journal of Physiology and Pharmacology 12:37.

12. Bhansali, R.R., Kumar, A., and Arya, H.C. 1978. In vitro introduction of adventitious shoots on stem explants of Boerhaavia diffusa L. Current Science 47: 551-552.

13. Chandan, B.K., Sharma, A.K., and Anand, K.K. 1991. Boerhaavia diffusa: A study of its hepatoprotective activity. Journal of Enthnopharmacology 31 (3) : 229-307.

14. Chesssin, M., De Borde, D., and Zipf, A. (Eds) 1995. Antiviral proteins in higher plants. CRC Press, Boca Ration, Florida, USA.

15. Chopra, G.L. 1969. Angiosperms, Sysytematics and Life Cycle. S. Nagin \& Co., Jalandhar, Punjab, India. pp. 361-365.

16. Chopra, R.N., Ghosh, S., Dey, P., and Ghosh, B.N. 1923. Pharmacology and therapeutics of Boerhaavia diffusa (punarnava). Indian Medicinal Gazette 68: 203-208.

17. Chopra, R.N., Nayar, S.L., and Chopra, I.C. 1956. Glossary of Indian Medicainal Plants. Council of Scientific and Industrial Research (CSIR), New Delhi, India.p. 39.

18. Cruz, G.L. 1995. Dicionario Das Plantas Uteis Do Brasil. $5^{\text {th }}$ Edition. Betrand, Rio de Janeiro, Brazil.

19. CSIR. 1998. The Wealth of India: Raw Materaials Vol. VII B. CSIR, New Delhi, India. P. 174.

20. Dhar, M.L., Dhar, M.M., Dhawan, B.N., Mehrotra, B.N., and Ray, C. 1968. Screening of Indian plants for biological activity: Part I. Indian Journal of Experimental Biology 6: 232-274.

21. El- Ghamery, A.A., A.I.El-Nahas and M.M.Mansour. 2000. The action of atrazine herbicide as an indicator of cell division on chromososmes and nucleic acid content in root meristems of Allium cepa and Vicia faba. Cytologia, 65: 277-287.

22. Gaitonde, B.B., Kulkarni, H.J., and Nabar, S.D. 1974. Diuretic activity of punarnava (Boerhaavia diffusa). Bulletins of the Haffkine Institute (Bombay, India) 2:24.

23. Gupta, R.B.L., Singh, S., and Dayal, Y. 1962. Effect of punarnava on the visual acuity and refractive errors. Indian Journal of Medical Research 50:428-434.

24. Heywood, V.H. 1978. Flowering Plants of the World. Oxford University Press, London, UK. Pp. 69-70.

25. Jain, G.K. and Khanna, N.M. 1989. Punarnavoside: A new antifibrinolytic agent from Boerhaavia diffusa Linn. Indian Journal of Chemistry 28 (B): 163-166.

26. Kempiak, G., Schuster, G., Aswathi, L.P., and Lluge, S. 1991. Attempts to reduce damage caused by oat sterile dwarf virus in oats using virazole, 2, 4-dioxohexahydrotriazine, Boerhaavia inhibitor and alkanemonosulfonate. Acta Phytopathologica et Entomologica Hungrica 26: 219-226.

27. Kadota, S., Lami, N., Tezuka, Y., and Kikuchi, T. 1989. Constituents of the roots of Boerhaavia diffusa Linn. I. Examination of sterols and structures of new rotenoids (boeravinones A and B). Chemical and Pharmaceutical Bulletin 37 (12): 3214-3220.

28. Kirtikar, K.R. and Basu, B.D. 1956. Indian Medicinal Plants. Vol. III. $2^{\text {nd }}$ Edition. Lati Mohan Basu, Allahabad, Uttar Pradesh, India. Pp. 2045-2048.

29. Kumar, P. and Aswathi, L.P. 2003a. Mangement of infection and spread of bottleground mosaic virus disease on bottleground through botanicals. Indian Phytopathology 56(3):36.

30. Kumar, P. and Aswathi, L.P. 2003b. Prevention of cucumber mosaic virus infection and spread in cucumber plants treated with Boerhaavia diffusa inhibitor. Indian Phytopathology 56(3):37.

31. Lami, N., Kadota, S., and Kikuchi, T. 1992: Constituents of the roots of Boerhaavia diffusa Linn. IV. Isolation and structure determination of boeravinones D, E and F. Chemical and Pharmaceutical Journal 38(6): 1558-1562. 
32. Mishra, A.N. and Tiwari, H.P. 1971. Constituents of the roots of Boerhaavia diffusa. Phytochemistry 10:3318.

33. Mitra, R and Gupta, R.C. 1997. "Punarnava - An Ayurvedic drug of repute". In: Applied Botany Abstracts, Vol. 17, No.3. Economic Botany Information Service, National Botanical Research Institute, Lucknow, UttarPradesh, India.pp.209-227.

34. Olukoya, D.K., Tdika, N and Odugbemi, T.1993."Antibacterial activity of some medicinal plants from Nigeria". Journal of Enthnopharmacology 39:69-72.

35. Seth, R.K., Khamala, M., Chaudhary, M., Singh, S and Sarin, J.P.S. 1986. "Estimation of punarnavocides, a new antifibrinolytic compound from Boerhaavia diffusa". Indian Drugs 23:583-584.

36. Shah, G.L., Yadav, S.S and Badinath, V. 1983."Medicinal plants from Dahana Forest". Journal of Economic and Taxonomic Botany 4:141.

37. Shrivastva, N. and Padhya, M.S.1995. "“"Punarnavine” profile in regenerated roots of Boerhaavia diffusa Linn. Ph.D. thesis", Lucknow University, Lucknow, Uttar Pradesh, India.

38. Singh, R.H and Udupa, K.N.1972. "Studies on the Indian indigenous drug punarnava (Boerhaavia diffusa Linn.). Part IV: Preliminary controlled clinical trial in nephritic syndrome". Journal of Research in Indian Medicine 7: 28-33.

39. Somashekar, R.K. and Goda, M.P. 1984. Effect of Fungicide vitavax on Allium cepa, Cytologia 49: 177-181.

40. Surange, S.R. and Pendse, G.S. 1972. "Pharmacognostic study of roots of Boerhaavia diffusa Wild. (punarnava)". Journal of Research in Indian Medicine 7:1.

41. Thakur, R.S., Puri, H.S and Husain, A.1989." Major Medicinal Plants of India”. Central Institute of Medicinal and Aromatic Plants (CIMAP), Lucknow, UttarPradesh, India. 116 pp 